\title{
EFFECTS OF GASTROINTESTINAL HELMINTH PARASITES ON RUMINANT NUTRITION
}

\author{
JAMES J. PARKINS AND PETER H. HOLMES \\ Glasgow University Veterinary School, Bearsden Road, Glasgow G61 1QH

\section{CONTENTS}

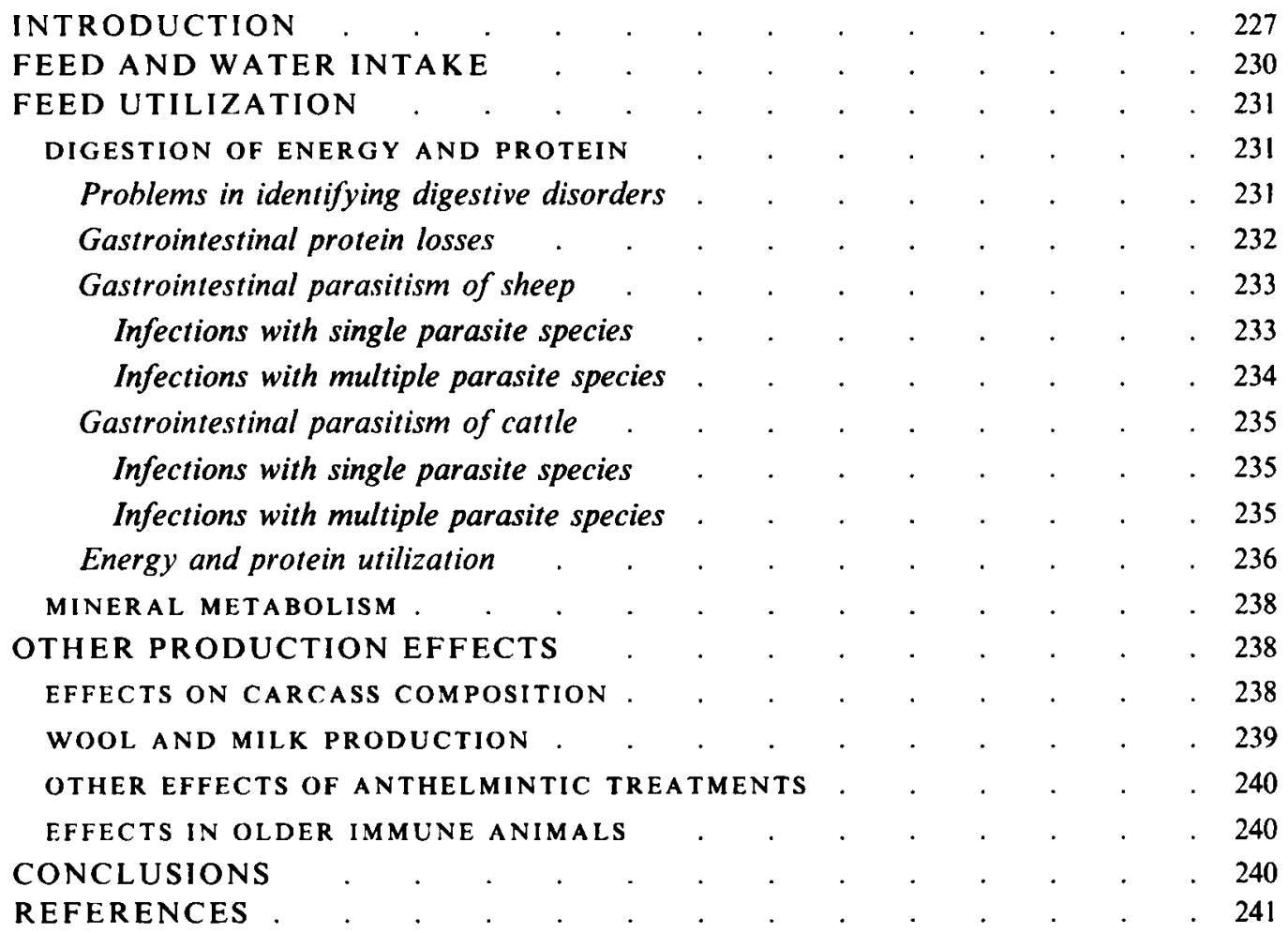

\section{INTRODUCTION}

Helminth parasites are a major cause of economic loss in ruminants throughout the world. Most losses are associated with gastrointestinal infections, although lungworms can also have a serious effect on ruminant productivity in many temperate areas of Western Europe and North America. Similarly, ectoparasites such as ticks and lice can have deleterious effects on growth rate, although their major veterinary importance is as vectors of various viral and protozoal diseases. Gastrointestinal helminth parasites incorporating pathogenic nematodes (worms) and trematodes (flukes) are the subject of this review.

Gastrointestinal helminthiases of ruminant animals have increasingly become an important focus of research attention over the last two decades. Following the early studies which were primarily concerned with the life cycle of the parasites and the pathological lesions they produced, more recent investigations have examined the pathophysiological 
Table 1. Major pathogenic gastrointestinal helminth parasites of domestic ruminants

\begin{tabular}{ll}
\multicolumn{1}{c}{ Location } & \multicolumn{1}{c}{ Genera } \\
\hline Abomasum & $\begin{array}{l}\text { Haemonchus, Ostertagia, Trichostrongylus } \\
\text { Semall intestine } \\
\text { Bunostonum, } \\
\text { Lesophagostomum, Chabertia } \\
\text { Large intestine }\end{array}$ \\
\hline
\end{tabular}

aspects of these infections and these studies have included a large component of nutritional experimentation.

This review is primarily concerned with the nutritional aspects. It is not meant to be exhaustive but rather attempts to highlight mainstream research and to speculate on future areas of investigation.

The major pathogenic helminth parasites of the gastrointestinal tract of ruminants are listed in Table 1. The clinical signs, parasitological and pathological features of the major nematode infections have been reviewed several times (e.g. Armour \& Ogbourne, 1982; Bremner, 1982; Sykes, 1983; Holmes, 1985). However, whereas the net result of infection is known, the relative importance and interaction of different influences on the course of the disease processes are still uncertain. The effects of gastrointestinal parasitism in ruminants are impaired production and even death. Where estimates of economic losses on a large scale have been attempted it is evident that more precise information on the various features of production loss are needed before accurate fiscal losses may be calculated. Heavy untreated infection may be fatal and an obvious cause of economic loss, but non-fatal infections, apart from resulting in poor productivity, also cause affected animals to be culled prematurely and others not to be used as replacement breeding stock.

Much recent work has uncovered deleterious effects on production in cases of parasite infection where clinical signs of the disease are not evident. Such 'subclinical' losses of production are clearly difficult to assess economically on any large scale and the attempts to quantify these effects properly are important (Coop, 1982).

The results of infection include: changes in liveweight gain or body-weight together with alteration in body composition; reduction in the quantity and quality of wool production in sheep; possible depressive effects on milk production in cattle and reproductive performance in breeding stock. The degree of derangement of normal function and the subsequent net result in animal output is determined by several factors which include: the particular species of parasite(s) and the weight of challenge, and the age, nutritional and immunological status of the host.

More recently, the importance of mixed infections of parasites, notably Ostertagia and Cooperia infection in cattle and Ostertagia and Trichostrongylus in sheep, have been clearly demonstrated (e.g. Randall \& Gibbs, 1981; Steel et al. 1982; Parkins et al. 1990).

Gastrointestinal parasitism is associated in clinical cases with inappetence and also frequently with profuse diarrhoea. Blood samples show hypoalbuminaemia and often a depressed total protein content. In severe cases of hypoalbuminaemia, facial oedema may develop, e.g. with Haemonchus contortus (Abbott, 1982) or Fasciola hepatica. Parasites affecting the abomasum result characteristically in increases in the concentration of serum pepsinogen and this is a useful aid in the diagnosis of abomasal trichostrongylosis.

The pathogenic nematode parasites of ruminants have direct life cycles. A diagram showing the life cycles of two important gastrointestinal parasites in cattle is shown in Fig. 1. Eggs passed in the faeces develop into larvae which grow through two further larval 


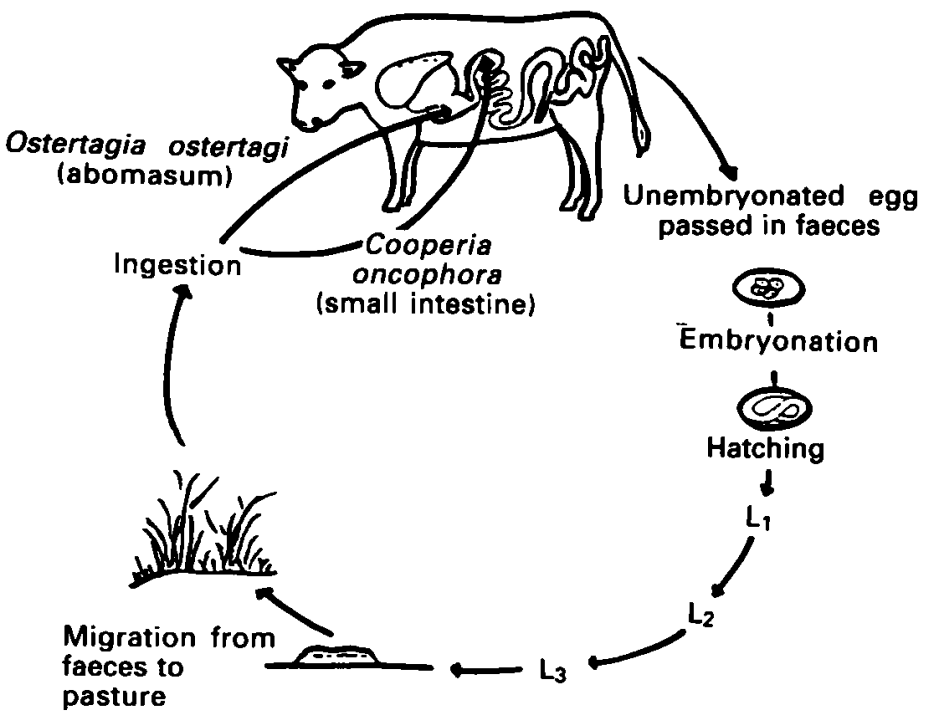

Fig. 1. Simplified life-cycle of two important gastrointestinal helminth parasites of cattle; Ostertagia ostertagi and Cooperia oncophora. $\mathrm{L}_{1}, \mathrm{~L}_{2}, \mathrm{~L}_{3}$, three larval stages.

stages. The third stage $\left(\mathrm{L}_{3}\right)$ larvae migrate onto herbage where they may be ingested by grazing ruminants. The development to the egg-laying adult stage passes through two further larval stages. In the case of Ostertagia, maturation from $\mathrm{L}_{3}$ to adult takes place within the gastric glands of the abomasum by $16-21 \mathrm{~d}$. There is much tissue damage particularly associated with the emergence of the adult worms into the abomasal lumen. As a result of loss of functional parietal cells, acid secretion is impaired and the $\mathrm{pH}$ in the abomasum becomes less acid, with plasma pepsinogen values rising in relation to the parasite burden.

Lesions associated with Haemonchus contortus are broadly similar to other abomasal trichostrongyle infections, but it is the haematophagic habit of the fourth stage larvae and adults and the resultant blood loss which is the main pathogenic feature. Trichostrongyle infections of the lower tract cause damage to the mucosa which results in mucosal sloughing and stunting of the villi. Most damage occurs in the proximal third of the small intestine and heavy infections are associated with severe enteritis.

Measures aimed at preventing clinical parasitic gastroenteritis generally attempt to avoid exposure of susceptible stock to heavily contaminated pasture during the latter part of the grazing season. This may be achieved by the strategic use of anthelmintics or grazing control, or both. Mixed or alternate grazing by cattle and sheep where pasture nematodes are mutually exclusive promotes the removal of $\mathrm{L}_{3}$ by the non-receptive host without harmful effect, thus reducing contamination for the receptive host. Mixed or alternate grazing by animals of the same species but different ages may be used to similar effect, the older immune animals reducing the contamination to which the younger susceptible animals are exposed. Theoretically rotational grazing systems promote the control of parasitic gastroenteritis by breaking the cycle of infectivity between the herbage and the host during periods when pastures are rested.

A variety of modern anthelmintic drugs are available with both broad and narrow spectrums of activity and these have been subject to recent reviews (Arundel, 1985; Behm \& Bryant, 1985; Marriner, 1986). Control strategies may be prophylactic, employing regular use of anthelmintics throughout the grazing season to remove existing worm 
burdens and prevent pasture contamination (Taylor et al. 1985), or may be instigated once clinical symptoms become apparent. However, severe production losses may result from both clinical and subclinical ostertagiasis and experimental studies suggest that in the latter case these may arise primarily from a reduction in voluntary food intake attributable to the continual presence of developing larvae in the abomasal mucosa (Sykes \& Coop, 1977).

Systems to control infection include medication of feed or drinking water (Downey et al. 1974; Jones et al. 1978) and intraruminal devices for cattle providing either pulsed or continuous medication with anthelmintics such as morantel tartrate (Armour et al. 1981; Jones 1981; Borgsteede et al. 1985), oxfenbendazole (Morgan \& Rowlands, 1986; Jacobs et al. 1987; Mitchell, 1987) and ivermectin (Pope et al. 1985; Egerton et al. 1986; Soll et al. 1988).

\section{FEED AND WATER INTAKE}

A common feature of infections with gastrointestinal nematodes and trematodes is a reduction in voluntary feed intake, and this is generally recognized as a major feature of the pathogenesis of such infections. The degree of inappetence can vary considerably. In moderate to heavy infections food intake can be reduced by $20 \%$ or more, whilst in lighter infections it may be less obvious (see Kloosterman 1971; Armour et al. 1973; Jordan et al. 1977; Albers, 1981; Randall \& Gibbs, 1981). The degree of inappetence has been shown to vary not only with the level and duration of parasitism, but also with the level of phosphorus (Coop \& Field, 1983) and protein intake (Abbott et al. 1985 b). In acute infections in which the parasite burden is gradually lost there is generally a slow restoration of appetite, whilst in chronic infections which are not expelled, e.g. F. hepatica, the appetite may remain depressed.

When feed intake is expressed per unit body-weight the relative feed intakes in chronically parasitized and control lambs may show only moderate differences (Sykes, 1982). This is associated with the reduced rate of skeletal growth and, hence, smaller body size of parasitized animals, and lower maintenance requirements. Nevertheless it is important to distinguish between primary and secondary effects in this regard, and it is generally agreed that reduced feed intake is a primary effect of parasitism. However, the underlying reason(s) for the inappetence are far from clear. A number of possible explanations have been reviewed by Symons (1985).

Several authors in the past have proposed that abdominal pain from local damage at the site of infection may be responsible. Certainly in severely affected sheep clinical signs associated with abdominal pain, such as teeth grinding and depression, are occasionally observed. However, these signs are not common and the true role of subjective factors such as pain is extremely difficult to assess.

In Fasciola infections appetite is not generally affected during fluke migration through the liver parenchyma, suggesting that liver damage per se is not important. There is, nevertheless, a good correlation between the onset and severity of feed intake depression and the development of anaemia and hypoproteinaemia in association with adult infections in the bile ducts (Berry \& Dargie, 1976). It is of interest that anaemia caused by phlebotomy has also been shown to reduce feed intake and growth in sheep (Alexander \& Kiesel, 1965).

Changes in abomasal $\mathrm{pH}$ have been frequently reported in ruminants infected with abomasal parasites such as Ostertagia spp. (Ritchie et al. 1966) and occasional cases of intestinal trichostrongylosis (Barker \& Titchen, 1982). Whether such changes are directly associated with changes in appetite is not known, but resultant alterations in protein digestion and the availability of amino acids for absorption could be important since the latter have been shown to stimulate appetite (Leng, 1981).

Kloosterman \& Henken (1987) have highlighted the important factors of the particular 
feeds offered to comparable groups of experimental animals, and the amounts offered and frequency. Clearly, palatability of the different components of a mixed diet may well affect the level of refusal by an infected animal. Abbott et al. (1986) recorded more feed refusal in lambs offered a low protein diet than those offered a high protein diet. The diets were essentially similar in composition, being complete diets incorporating a mixture of short length roughage, sugarbeet pulp and soya-bean meal. However, often where concentrate feeds are on offer together with a separate roughage component it is the less digestible roughage which tends to be primarily refused (e.g. Zemmelink, 1980; Albers, 1981; Entrocasso, 1984). Selection of components can greatly confuse nutritional studies and the earlier studies may well have overlooked this problem.

It is also possible that alterations in gastrointestinal motility and digesta flow, even in the absence of diarrhoea, could be linked with changes in voluntary feed intake (Gregory, 1985). Where studied, e.g. Gregory et al. (1985), the rate of flow through the gut was reduced rather than increased. Also Bueno et al. (1982) showed that heavy infection with Haemonchus can produce diarrhoea and changes in normal gastrointestinal motility. With clinical infections the onset of diarrhoea is preceded by disruption of the migrating myoelectric complex (MMC) and severe inhibition of the reticulo-rumen and abomasum. These changes and the related reduction in the feed intake could be directly associated with changes in the levels of gastrointestinal hormones, such as gastrin, which have been shown to be elevated in parasitized ruminants (Titchen, 1982; McKellar et al. 1986; Fox et al. 1987). It is known that gastrin is capable of inhibiting food intake in hungry sheep (Grovum, 1981), reduces the frequency of reticular contractions (Ruckebusch, 1971), inhibits abomasal emptying (Bell \& Grivel, 1975) and can seriously affect the normal MMC pattern of the small intestine (Gregory, 1985). More recently it has been shown that artificially raised gastrin levels in worm-free animals by administration of the gastric acid secretion inhibitor, omeprazole, results in a significant drop in feed intake (up to $40 \%$ ) and a rise in gastrin levels comparable to those seen in Ostertagia-infected calves (Fox et al. $1989 b$ ).

Food intake in ruminants, on a roughage diet at least, is controlled chiefly according to the level of reticulo-ruminal distension, with additional effects from the level of abomasal and intestinal distension (Grovum \& Phillips, 1978; Grovum, 1979). Therefore, if reticuloruminal motility is depressed in parasitized animals this could also lead to reduced feed intake.

In lambs infected with $T$. colubriformis it has been reported that digesta flow was reduced from the rumen (Roseby, 1977), and recent studies by Rowe et al. (1988) suggest that rumen fermentation and flow rates are altered in sheep infected with $H$. contortus.

Water intake and water retention are commonly increased in parasitized ruminants (Parkins et al. 1982a, b; Abbott et al. 1986; Entrocasso et al. 1986a, b; Rowe et al. 1988). Increases in water retention are associated with elevations in tissue water content, changes in body water turnover (Holmes \& Bremner, 1971) and also expansion in the plasma volume. The causes of these alterations in fluid balance have not been examined in any detail. Such changes in water retention, however, clearly demonstrate that tissue loss attributable to parasitic infections cannot be reliably determined from changes in bodyweight alone.

\section{FEED UTILIZATION \\ DIGESTION OF ENERGY AND PROTEIN}

\section{Problems in identifying digestive disorders}

Impairment of feed digestion, energy and nitrogen utilization in the parasitized animal are obvious factors contributing to reduced performance. It may well be that reduced feed 
intake is singly the most important factor in many acute situations (Holmes, 1986), but the relative contributions of this and other impairments are particularly difficult to assess in practical situations. In field studies it is usual to compare production indices in naturally infected animals with those of anthelmintic-treated animals. The grazing at the outset has to be as similar as possible with respect to the larval challenge and availability and area of grass; but frequently such split-plot procedures eventually produce end situations where the pasture availability and contamination is quite different between the treatment groups mainly owing to the depressed appetites of infected animals.

Nevertheless, these types of field study are invaluable in the quantification of many production characteristics which may not be apparent in laboratory studies. In recent years it has been possible to undertake detailed pathophysiological and metabolism studies in the laboratory where, using controlled pair-feeding regimes (i.e. where infected and control animals receive the same amount of feed), differential effects on various physiological and metabolic variables can be separated from those attributable to intake effects alone.

Much work has been conducted with sheep in the laboratory in studies on both acute infection, when one large single infective dose is administered, and so-called 'trickle' infections, in which daily doses of infective larvae are given in an attempt to mimic natural grazing infection. Also, detailed metabolism studies examining events at specific sites of nutrient digestion and absorption using strategically placed cannulas have been performed almost exclusively in sheep (e.g. Poppi et al. 1981; Rowe et al. 1982; Bown et al. 1984).

Until quite recently very few large trials had been performed with cattle, because of the technical difficulties and high costs. However, much of the recent work reviewed here was undertaken with cattle. Practical difficulties with complete collection of faeces and urine from cattle kept in digestion study accommodation are increased whenever the faecal output becomes diarrhoeic, as in the acute phase of bovine ostertagiasis. Entrocasso (1984) and Taylor (1988) described useful improvements in the methods which may be used to collect faeces and urine from such animals.

Standard procedures for the measurement of apparent digestibility and balance of feed fractions can only assess the net result of digestive and absorptive function in the animal. True digestive efficiency cannot be determined directly because of the significantly increased passage of endogenous $\mathbf{N}$ (including plasma protein leakage), mucus and other materials in parasitized animals. Using standard techniques, alterations in apparent digestibility of feed fractions have not often been demonstrated in parasitized animals, and this has led to an acceptance by some that depression of these processes is not particularly important in the overall disease process (e.g. Coop et al. 1982; Symons, 1985). But this may not be strictly true, since it is difficult to evaluate experimentally the specific dysfunction effect of a parasitic burden, whose predilection site within the animal gives rise to pathogenic consequences which may be compensated for by non-affected regions of the gut. However, because of the known structural damage and altered motility resulting from parasitic infection many efforts have been made to examine the digestive efficiency and absorption effects on the apparent poor nutrient utilization.

Ultimately it is the efficiency of energy and $\mathrm{N}$ utilization which affects production performance. However, few experiments have detailed the apparent effects of parasite infections on digestion of the crude proximate fractions of the feed in pair-feeding studies.

\section{Gastrointestinal protein losses}

An important step in understanding the pathophysiology of gastrointestinal helminth infections was the observation that they are usually associated with hypoalbuminaemia and, in some cases, with anaemia. Such changes can be brought about by alterations in rates of synthesis and breakdown or by altered distribution. The application of 
radioisotopic techniques has allowed accurate quantification of these various possibilities in a wide range of parasitic infections. As a result of such studies it is now appreciated that a distinctive feature of such infection is loss of proteins into the gastrointestinal tract. Associated with the loss of plasma proteins and erythrocytes into the gastrointestinal tract there is a rise in the catabolic rate of albumin and an increased turnover rate of erythrocytes. The proteins represent plasma and erythrocytes, exfoliated epithelial cells and mucus. Losses of plasma proteins can be very high (Table 2), and in infections associated with gastrointestinal haemorrhage, such as $H$. contortus, Oesophagostomum radiatum and Fasciola spp., there is also a massive loss of erythrocytes (Holmes et al. 1968; Bremner, 1969; Holmes \& Maclean, 1971; Dargie, 1975; Holmes et al. 1986). Unfortunately methods for quantifying losses of exfoliated epithelial cells and mucus are not available. However, there is little doubt that they are increased in many types of gastrointestinal parasitism (Armour et al. 1966; Coop \& Angus, 1975; MacDonald \& Ferguson, 1978; Rowe et al. 1982; Poppi et al. 1986). Poppi et al. (1981) suggested that in an infection study with T. colubriformis plasma protein accounted for only $20 \%$ of the total $\mathrm{N}$ loss and that over half this was absorbed lower in the small intestine. In contrast, Rowe et al. (1982) showed in sheep infected with $H$. contortus and in sheep in which blood was infused directly into the abomasum that all the blood could be accounted for by the increased $\mathrm{N}$ flow into the duodenum, and that all was absorbed by the ileum.

\section{Gastrointestinal parasitism of sheep}

Infection with single parasite species. Many of the earlier reports were largely concerned with Ostertagia and Trichostrongylus infections of sheep. Parkins et al. (1973), with o. circumcincta infection in sheep, reported a marked negative $\mathrm{N}$ balance due to both a reduction in voluntary feed intake and an increased urinary $\mathrm{N}$ excretion; a simultaneous marked rise in plasma urea concentration was noted. Digestion studies showed some reductions in the apparent digestibilities of dry matter, organic matter, crude fibre and crude protein $(\mathrm{N} \times 6.25)$ fractions. The most marked reductions in $\mathrm{N}$ balance were noted in those animals given lower-protein-containing diets and helped support previous speculations that differences in the nutritional status of the host could possibly moderate the adverse effects of infection. Later, Sykes \& Coop (1977) showed a marked reduction in $\mathrm{N}$ digestion when sheep were infected daily with $4000 \mathrm{O}$. circumcincta larvae, but not in sheep infected with $2500 \mathrm{~T}$. colubriformis larvae (Sykes \& Coop, 1976). In the same experiments small reductions in apparent gross energy digestion were recorded for $O$. circumcincta infection but not with $T$. colubriformis. MacRae et al. (1982) using the same inoculation rate of $T$. colubriformis presented findings to show a lowered metabolizability (but with little effect on methane and urine energy losses) which suggested a reduction of about $10 \%$ in apparent gross energy digestion.

Steel et al. (1980) recorded increased enteric loss of plasma in $T$. colubriformis infection of sheep which was directly related to the magnitude of the larval challenge. Earlier, Steel (1974) had shown that the same parasite markedly altered the rates of nutrient uptake in different parts of the gastrointestinal tract and where non-ammonia-N (NAN) outflow was increased from the ileum. Similar disturbances in NAN flow were noted in sheep infected with $O$. circumcincta (Steel, 1978), and it was assumed that most of the endogenous NAN lost into the abomasum is re-absorbed along the small intestine.

The effect of prolonged subclinical infection with $T$. colubriformis (2500 larvae/d for 34 weeks) on $\mathrm{N}$ metabolism of lambs was reported by Kimambo et al. (1988). Growth was depressed during weeks $6-13$ as a result of inappetence and lowered $\mathrm{N}$ digestibility. The lambs had been surgically fitted with abomasal and ileal cannulas and during the 6-13 week period more $\mathbf{N}$ flowed to the terminal ileum and plasma protein leakage was at its height. 
Table 2. Plasma and erythrocyte losses into the gastrointestinal tract of ruminants (sheep and calves) infected with gastrointestinal helminths

\begin{tabular}{|c|c|c|}
\hline Parasite & $\begin{array}{l}\text { Plasma loss } \\
(\mathrm{ml} / \mathrm{d})\end{array}$ & $\begin{array}{l}\text { Erythrocyte } \\
\text { loss (ml/d) }\end{array}$ \\
\hline \multicolumn{3}{|c|}{ Sheep } \\
\hline Haemonchus contortus & 270 & 31 \\
\hline Ostertagia circumcincta $(\mathrm{Oc})$ & 90 & - \\
\hline Trichostrongylus colubriformis (Tc) & 170 & 一 \\
\hline Mixed $\mathrm{Oc}$ and $\mathrm{Tc}$ & 205 & - \\
\hline Fasciola hepatica & 160 & 17 \\
\hline Worm-free controls & 40 & $<1$ \\
\hline \multicolumn{3}{|c|}{ Calves } \\
\hline Oesophagostomum radiatum $\dagger$ & 970 & 39 \\
\hline Cooperia oncophora (Co) & 850 & - \\
\hline Ostertagia ostertagi (Oo) & 500 & - \\
\hline Mixed Co and Oo & 900 & 一 \\
\hline Worm-free controls & 300 & $<2$ \\
\hline
\end{tabular}

* Bown et al. (1984), assuming plasma to contain $60 \mathrm{~g}$ protein/1.

+ Bremner (1969).

Microbial protein digestion was also depressed towards the later part of the period but it was unclear whether this was an artefactual effect.

Work with $H$. contortus infection in sheep reported by Abbott (1982) and Abbott et al. $(1985 a, b)$, using pair-fed sheep and experimental diets which differed only in protein content, showed that the level of protein intake did not influence the establishment of single primary infections, but lambs offered the lower protein diet displayed more severe clinical signs despite similar blood losses. Loss of appetite was a feature of the disease, particularly in infected lambs given the low protein diet, but there were no differences in the digestibility of the various dietary proximate fractions or in $\mathbf{N}$ losses in urine and faeces.

More recent work with $H$. contortus infections in sheep given a complete diet containing $80 \mathrm{~g}$ digestible crude protein and $9.7 \mathrm{MJ}$ metabolizable energy (ME)/ $\mathrm{kg}$ dry matter (DM) ad lib. (Stevenson, 1989) showed little effect on feed utilization or growth and body composition over a $53 \mathrm{~d}$ period post infection, even though digestion and $\mathrm{N}$ balance were apparently adversely affected. Patent infections had been established and a moderate anaemia was evident. In a subsequent study restriction of daily feed intake to either 1 or $1.5 \mathrm{~kg}$ DM showed that a single infection with $H$. contortus markedly affected body composition and feed utilization, these effects being more pronounced in lambs maintained on the lowest level of feed intake.

Infections with multiple parasite species. It was Steel (1978) who suggested that concurrent infections of $O$. circumcincta and $T$. colubriformis might cause incomplete reabsorption of the $\mathrm{N}$ lost in the abomasum and that the overall $\mathrm{N}$ absorption could be much worse than in a monospecific infection. Coop et al. $(1986,1988)$ found only marginal additive effects of combined $O$. circumcincta and $T$. vitrinus infections on the depression of growth rate in lambs. This contrasted with the findings of Steel et al. (1982) for mixed infections of $T$. colubriformis and $O$. circumcincta where liveweight gain and wool growth were depressed to a greater extent than the expected sum of individual infections. This was attributed to a reduction both in feed intake and in the efficiency of retention of apparently digested $\mathbf{N}$. It was speculated that, even though the faecal $\mathbf{N}$ output was no greater than expected, an increased amount of undigested endogenous $\mathbf{N}$ was degraded to ammonia in the large intestine and eventually lost in the urine. 
Bown et al. (1984) also examined the effects of a mixed infection with these nematodes in sheep fitted with cannulas in the abomasum, duodenum and terminal ileum. Sustained appetite depression resulted, together with a marked plasma protein loss (Table 2). Infection did not affect the digestion and absorption of albumin protein across the site of intestinal infection (which was also very low in the pair-fed control animals), but absorption across the whole small intestine was high. The authors, thus, concluded that deleterious effects of infection were a result of increased endogenous $\mathbf{N}$ losses and not impaired re-absorption.

\section{Gastrointestinal parasitism of cattle}

Infections with single parasite species. Recently, Fox et al. (1989a) dosed calves with the daily equivalent of $10000 O$. ostertagi infective larvae for 6 weeks. Feed intake was depressed and, not unexpectedly, apparent protein digestibility declined. Interestingly the appetite depression was considered to be responsible for the observed increases in blood urea and non-esterified fatty acids and the decrease in blood calcium attributed to either the hypoalbuminaemia or a supposed impairment of intestinal mineral absorption.

A series of experiments were conducted under standardized laboratory conditions of diet, feed intakes, animals and larval challenges which examined the separate and combined effects of $O$. ostertagi and $C$. oncophora infections in calves at levels of larval challenge known to be commonly encountered under natural grazing conditions in the UK.

First, Armour et al. (1987) infected calves with 10000 C. oncophora larvae daily for 6 weeks, which resulted in reduced digestibility of dry and organic matter, crude fibre and gross energy. The infection also resulted in a lowered $\mathbf{N}$ retention in which urinary $\mathbf{N}$ outputs were significantly increased. The subsequent study compared calves given a daily low level infection with $2000 \mathrm{O}$. ostertagi larvae over a 6-week period (Taylor et al. 1989). Pathophysiological changes were evident, but without acute clinical disease. There were no effects on the digestibility of the complete diet on offer and no overall effects on apparent $\mathrm{N}$ retention, except for a temporary increase in urinary $\mathrm{N}$ output.

Infections with multiple parasite species. Under natural field conditions both concurrent and sequential infections of $O$. ostertagi and $C$. oncophora occur. During the early grazing season low numbers of both species are ingested with pasture to establish small host-parasite populations. Due to the superior fecundity of $C$. oncophora it is reasonable to suppose that host populations of this nematode initially increase more quickly than those of $O$. ostertagi. However, as a result of the rapid development of host immunity to $C$. oncophora, $O$. ostertagi predominates during the later part of the grazing season.

Jordan et al. (1977) in an early study with feed-lot steers, carrying only low mixed parasite burdens, showed no effect at all on apparent digestibility, ME and efficiency of energy utilization. Randall \& Gibbs (1981), however, in a mixed infection of $O$. ostertagi and $C$. oncophora showed significant reduction in apparent crude protein and energy digestibility in cattle displaying clinical signs of gastroenteritis 3-4 weeks after infection. In another subclinically infected group only insignificant effects on protein digestion were seen, but with a clear depression in energy digestibility; however, ME intake was much lower in the clinical group at that time. Parkins et al. (1982a) reported an experiment with calves naturally infected with $O$. ostertagi and moderate numbers of $C$. oncophora and Nematodirus helvetianus at summer grazing and treated at housing with thiabendazole. Growth was significantly lowered in the earlier weeks following housing. There were only small reductions in apparent digestive efficiencies, but an overall poorer $\mathbf{N}$ retention in infected cattle attributed to increased losses in both urine and faeces. Daily water output in both faeces and urine was greater in the parasite groups, with blood protein lower and urea concentration raised. It was reasoned that the high-protein-intake diet given may have reduced the severity and consequences of the reduced $\mathbf{N}$ balance. In a following experiment 
(Parkins et al. 1982b), groups of calves were naturally infected with $O$. ostertagi at grass and either left untreated or treated with fenbendazole. The dietary allowance following housing supplied sufficient ME for $0.5 \mathrm{~kg}$ daily gain but only $60 \%$ of the required digestible crude protein (DCP). Growth rates were poorest in the untreated parasitized group. Again interestingly, water intake and output were greatest in these infected cattle. There were no significant reductions in digestibility of any feed fraction other than a marked effect on crude protein, but retention of $\mathrm{N}$ was significantly reduced in the parasite group mainly due to increased urinary $\mathrm{N}$ excretion. It was concluded here that, under conditions of suboptimal protein intake, nematode infection can markedly affect production even following efficient anthelmintic treatment. Clearly prevention of the disease is preferable to the cure, which in turn is better than no treatment at all, since later work by Entrocasso et al. (1986a) showed decreased digestibility of the whole diet in winter-housed cattle which had displayed clinical type 1 ostertagiasis during grazing; here the natural infection at pasture again included both Ostertagia and Cooperia species. Digestibility was particularly reduced for DM, crude protein and gross energy. Balance studies conducted throughout the winter period showed that both increased urine and faecal $\mathrm{N}$ losses were important in significantly reducing the overall $\mathrm{N}$ retention. These effects were reported as being most apparent during clinical type II ostertagiasis, which occurred after 17 weeks of housing as a result of the emergence of inhibited larvae in the abomasum. It was postulated that the 'development of a strong immunity to $C$. oncophora and the loss of existing infections during the winter' suggested that the changes were mainly attributable to $O$. ostertagi. The significant reduction in energy digestion was not reflected in body-weight gain differences but body composition was adversely affected. There is a lack of comparative information on type II ostertagiasis. However, the significance of the weight difference potential attributable to the digestive efficiency loss was calculated to be outside the measurement limit of sensitivity of the experiment.

Verstegen et al. (1989) reported a trial using pair-fed control calves and calves continuously infected with $O$. ostertagi and $C$. oncophora. Mean crude protein digestibility was slightly depressed $(3.2 \%)$ over the first 8 weeks post infection and gross energy digestibility was also similarly reduced.

A concurrent daily infection in calves of $2000 \mathrm{O}$. ostertagi and $10000 \mathrm{C}$. oncophora infective larvae, also over a 6-week period, gave rise to acute parasitic gastroenteritis, inappetence, weight loss, hypoalbuminaemia and diarrhoea (Parkins et al. 1990). There were consistent and significant depressions in digestibility and $\mathrm{N}$ retention. Marked effects were not apparent until 5-6 weeks post infection, at which time the crude protein and gross energy digestibilities were depressed, but the increase in urinary $\mathbf{N}$ loss was only small. The deleterious effects of infection were essentially eliminated in calves given a morantel sustained-release bolus (see also Armour et al. 1987 and Taylor et al. 1989).

Combined infection clearly contrasted with the monospecific infections in which lesser differences in apparent digestive efficiency were reported.

\section{Energy and protein utilization}

Many balance studies have demonstrated that reduced $N$ retention is often a characteristic feature of gastrointestinal parasitisn. This very often results from increased urinary $\mathrm{N}$ loss, implying a reduction in the efficiency of utilization of absorbed amino acids. The radioisotopic techniques referred to earlier have shown that high levels of blood protein loss into the gastrointestinal tract are a consistent finding in helminth infections, but the increases in faecal $\mathrm{N}$, as reported by Sykes \& Coop (1977) and Symons et al. $(1981 a)$, may represent only a relatively small proportion of the total endogenous protein loss which has escaped absorption. Poppi et al. (1981), using cannulated sheep infected with 
$T$. colubriformis, demonstrated no differences in the true digestibility of ${ }^{35} \mathrm{~S}$-labelled bacteria in the small intestine or apparently digested $\mathrm{N}$ over the whole tract, thus confirming the earlier findings of Symons \& Jones (1970). However, there were plasma protein losses into the small intestine with an increased ileal $\mathrm{N}$ outflow and urinary $\mathrm{N}$ excretion. Stevenson (1989), commenting on these observations, regarded the deduction that a large part of the extra ileal $\mathrm{N}$ was cell sloughing and mucin secretions as unlikely in view of its relative indigestibilty. Indeed Rowe et al. (1982) showed that blood loss accounted for nearly all the additional abomasal $\mathrm{N}$ outflow which was seemingly reabsorbed before the terminal ileum. Roseby (1977), working with $T$. colubriformis infection, has shown increases in the caecum-proximal colon volatile fatty acid and ammonia concentrations and pool sizes and speculated that increased microbial fermentation occurred. Microbial deamination of amino acids would result in an increase in ammonia absorption at the expense of amino acid uptake. Interestingly, Roseby \& Leng (1974) recorded increased urea synthesis rates, and other workers (e.g. Parkins et al. 1973; Dargie, 1980) also observed increased plasma urea concentrations. Protein digestion is initiated in the abomasum and completed in the proximal small intestine, liberated amino acids being mainly absorbed from the mid-third of the small intestine (Steel \& Symons, 1982). O. ostertagi infection is thought to bring about $\mathrm{pH}$-mediated limitation on abomasal protein digestion, but in a monospecific infection this is nullified by a compensatory increase in digestion in the small intestine. In a combined $O$. ostertagi and $C$. oncophora infection study (Parkins et al. 1990), the colonization of the small intestine by $C$. oncophora and associated mucosal damage may well have prevented any compensatory response and, thereby, the reported crude protein digestibility reduction. In addition the greatly increased plasma loss would have contributed to the increased faecal $\mathrm{N}$ loss. Some degradation of the extra $\mathbf{N}$ entering the gastrointestinal tract to produce ammonia may have been responsible for increased urinary $\mathrm{N}$ loss in infected calves. Also it was speculated that increased turnover of epithelial cells and plasma albumin were responsible in part for the reduced digestible energy of the feed. Sykes \& Coop (1977) had previously calculated that a $40 \%$ reduction in the efficiency of use of ME could be accounted for by the synthesis of 20-30 $\mathrm{g}$ protein to compensate for additional endogenous protein loss during acute infection.

Kloosterman \& Henken (1987) attempted to evaluate $\mathrm{N}$ and energy utilization efficiencies from a limited review of published values. For protein utilization, the $\mathrm{N}$ balance expressed as a proportion of the apparently digested nitrogen was used. The results and calculation using other available values (e.g. Parkins et al. 1982a, $b$; Entrocasso et al. $1986 a, b$; Armour et al. 1987; Taylor et al. 1989) show this approach to be of limited value because of the direct effects that the level of feeding above maintenance and the protein content of the diet exert.

For energy utilization the apparently retained energy (energy balance) expressed as a percentage of ME (digestible energy minus urine and methane energy losses) was used. Carcass analyses (e.g. Sykes \& Coop, 1976, 1977; Coop et al. 1982; Stevenson, 1989) or calorimetric measurement (Randall \& Gibbs, 1981; Van Adrichem et al. 1987; Verstegen et al. 1989; Stevenson, 1989) are experimental approaches used to determine energy balance. Reductions in the digestion of the gross energy of the complete diet have been frequently reported in a range of helminth infections in both cattle and sheep (e.g. Sykes \& Coop, 1977; Randall \& Gibbs, 1981; MacRae et al. 1982; Entrocasso et al. 1986a; Verstegen et al. 1989; Parkins et al. 1990). Sykes \& Coop $(1976,1977)$ found the gross efficiency of utilization of ME for growth was reduced by 30 and $37 \%$ for $O$. circumcincta and $T$. colubriformis infections respectively. Increased heat production may be expected to accompany the previously described increases in protein turnover, but there appear to be no reports of such increases. 
A detailed investigation of the partitioning of dietary energy in subclinical haemonchosis using direct calorimetry (Stevenson, 1989) showed faecal and urinary energy losses not to be significantly reduced by infection with $350 \mathrm{H}$. contortus $/ \mathrm{kg}$ liveweight, nor was there any effect on heat production. However, infected animals lost a greater proportion of dietary energy as methane. Energy retention and the efficiency of utilization of $\mathrm{ME}$ for gain purposes were not significantly different. Unfortunately the establishment of the infection was particularly low in this study. Level of feed intake affects heat production and where the gross efficiency of energy utilization was apparently impaired in infected animals this was largely because of reduced intake. However, net efficiency of utilization of $\mathrm{ME}$ for production (i.e. feed ME less maintenance cost) is related to the energy density of the complete diet, and in the calorimetry findings reviewed (Kloosterman \& Henken, 1987) derived maintenance and net efficiency values were extremely varied and generally not related to infection. Findings from carcass evaluation (e.g. Sykes \& Coop, 1976, 1977; Coop et al. 1982; Stevenson, 1989), however, show infected animals to have a lower energy retention. There is clearly a shortage of information and understanding of energy metabolism in parasitized ruminants. The differences in utilization of $\mathrm{ME}$ and protein in the growing ruminant may be manifest in the composition of the carcass, in that fat and muscle protein syntheses are affected.

\section{MINERAL METABOLISM}

A number of workers have demonstrated that skeletal growth and mineralization are impaired in sheep infected with $T$. colubriformis (Reveron et al. 1974; Sykes \& Coop, 1976), T. vitrinus (Sykes et al. 1979) or O. circumcincta (Sykes et al. 1977). For example, Sykes et al. (1977) found that lambs infected by continuous dosing with $O$. circumcincta deposited bone minerals ( $\mathrm{Ca}$ and $\mathrm{P}$ ) at only $35 \%$ of that of non-infected pair-fed controls. In lambs infected with $T$. colubriformis the effect was even greater and almost complete cessation of skeletal growth and mineralization has been reported (Sykes \& Coop, 1976).

There are several possible causes of impaired skeletal growth in parasitized sheep, and these appear to be related to the level and site of infection. In lambs infected with the abomasal parasite $O$. circumcincta the skeletal changes have been attributed to deficiencies of protein and energy induced by the parasite leading to a matrix osteoporosis (Sykes et al. 1977). The results of experiments using ${ }^{45} \mathrm{Ca}$ and ${ }^{32} \mathrm{P}$ by Wilson \& Field (1983) support this view, since neither $\mathrm{P}$ nor $\mathrm{Ca}$ absorption were found to be affected.

In sheep infected with $T$. colubriformis and other intestinal nematodes, reduced bone matrix synthesis due to an induced protein deficiency probably also occurs, but is exacerbated by a reduction in the apparent absorption of P (Sykes \& Coop, 1976; Poppi et al. 1985) and the true absorption of $P$ (Wilson \& Field, 1983). There are also increased losses of endogenous $\mathrm{P}$ and $\mathrm{Ca}$ as a result of intestinal parasitism, but apparently not with abomasal infections (Wilson \& Field, 1983).

The net effect of this is to induce a $P$ deficiency, leading to a reduced flow of salivary $P$ and a reduction in the plasma concentration of $P$ (Coop \& Field, 1983). The effect on Ca metabolism was found to be limited to an increase in endogenous faecal excretion.

\section{OTHER PRODUCTION EFFECTS \\ EFFECTS ON CARCASS COMPOSITION}

Entrocasso et al. (1986b) clearly demonstrated that the carcasses of cattle which had been exposed to a natural mixed trichostrongyle infection over two grazing seasons had significantly poorer killing-out percentages and associated carcass measurements, and in particular the total masses of muscle and fat were depressed in affected animals. These 
findings were also supported by Kruse (1986) and Garriz et al. (1987) who described similar significant effects of gastrointestinal parasitism on muscle, fat and bone composition of the carcass. Significant carcass compositional differences were found in growing sheep infected with $H$. contortus (Stevenson, 1989), in which there were also significant differences in the lowered total quantities of stored energy and protein.

A series of studies by Symons and his co-workers to examine tissue protein synthesis using $\mathrm{L}-\left[{ }^{14} \mathrm{C}\right]$ leucine and $\mathrm{L}-\left[{ }^{14} \mathrm{C}\right]$ tyrosine in parasitized animals is particularly relevant (Symons, 1985), since protein synthesis was reduced in skeletal muscle of pair-fed controls as well as infected sheep. However, in later experiments with tyrosine (Jones \& Symons, 1982), the fractional synthetic rate (FSR) and protein synthesis/d by the semitendinosus muscle and kidney cortex were reduced in infected animals but not in pair-fed controls, although the level of inappetance was much less than in the earlier studies. The rate of protein synthesis by the liver was increased in infected animals but not in pair-fed controls. Earlier studies showed that protein synthesis by homogenates of wool follicles of sheep with trichostrongylosis was depressed by over 50\% (Symons \& Jones, 1975).

Measurements of protein synthesis by the gastrointestinal tract have been restricted to guinea-pigs infected with $T$. colubriformis. In such animals the amount of protein synthesis/d was increased in both the small and large intestine (Symons \& Jones, 1983). It is important that this finding is confirmed in ruminants as these sites of increased protein synthesis may be an important cause of reduced nutrient utilization by infected sheep and cattle.

As a result of such studies Symons (1985) concluded that due to inappetance, gastrointestinal losses of protein and increased rates of gastrointestinal tissue protein metabolism, there is a net movement of amino acid- $\mathrm{N}$ from muscle and skin to the liver and gastrointestinal tract which decreases the availability for growth and milk and wool production.

\section{WOOL AND MILK PRODUCTION}

It has been recognized for some time that gastrointestinal parasites can adversely affect wool production (Donald, 1979). The inter-relationship between wool production and the level of exposure to trichostrongyle infections has recently been studied in weaner lambs. The threshold level of exposure for impairing wool growth was found to be between 950 and $3000 \mathrm{~T}$. colubriformis larvae/week, with the maximal effect occurring during the first 12 weeks (Steel et al. 1980). In the case of $O$. circumcincta an intake of more than 1200 larvae/week was required to produce significant effects (Symons et al. 1981b). When lambs were concurrently infected with $T$. colubriformis and $O$. circumcincta, production losses were exacerbated and wool growth was reduced by up to $66 \%$ (Steel et al. 1982).

Recently there has been considerable interest in the possible effects of trichostrongylosis on milk production. Early studies indicated that anthelmintic treatment of clinically healthy dairy cows around the time of parturition caused a significant increase in milk yield (Bliss \& Todd, 1973, 1976). However, later trials have provided conflicting results, despite the use of large numbers of animals, with some workers reporting improvements in milk yield (e.g. McBeath et al. 1979; Bliss et al. 1982), whilst others have found no significant beneficial effects following treatment (Baker, 1979; Michel et al. 1982). Very few experiments have been conducted in sheep to evaluate the impact of trichostrongylosis on milk production. In one study milk production was reduced by $17 \%$ in ewes infected with $O$. circumcincta (Leyva et al. 1982). In another recent experiment ewes infected with $H$. contortus showed a marked weight loss and gave $23 \%$ less milk than control animals, despite a similar feed intake (Thomas \& Ali, 1983). 


\section{OTHER EFFECTS OF ANTHELMINTIC TREATMENTS}

In addition to the known adverse effects of the worms themselves in helminth diseases, there has been a report of a depression of performance following the use of the anthelmintic fenbendazole every 2 weeks at the therapeutic level in order to simulate parasitologically clean animals (Entrocasso et al. 1986a, b).

Also, the effects of graded doses of intraruminally administered levamisole hydrochloride in $O$. circumcincta infection in lambs were studied by Parkins et al. (1988). Lambs were orally infected with $4000 \mathrm{O}$. circumcincta daily for $21 \mathrm{~d}$. Apparent digestibilities in untreated, infected lambs for DM and crude fibre were significantly reduced, but the higher daily doses of levamisole $(3.0 \mathrm{mg} / \mathrm{d})$ also resulted in significant reductions of digestibility of all the major feed fractions. Levamisole, in common with some substituted benzimidazoles (Jara et al. 1984; Hodgson \& Jessop, 1987), can apparently adversely affect rumen fermentation by suppression of cellulolytic and carbohydrate-dependent microorganisms. Inhibition of acid secretion in the abomasum (Fellenius et al. 1981) may have been responsible for the reduction of crude protein digestion.

The importance of some of these findings is particularly relevant to the current development programmes investigating the use of rumen-indwelling devices designed to administer anthelmintic drugs, either continuously or in a controlled series of 'pulse' doses.

\section{EFFECTS IN OLDER IMMUNE ANIMALS}

The immunological status and age of the host may also influence the effects of nematode infections. The majority of experimental infections have been conducted in young ruminants, and it is in such animals that the major effects of infection are observed. However, it is now becoming apparent that older animals at pasture which are generally judged to be relatively immune, on the basis of low parasite burdens, may suffer production losses when exposed to larval challenge (Anderson, 1973; Barger \& Southcott, 1975). Later studies by Yakoob et al. (1983) confirmed that immune ewes challenged with a mixed trichostrongyle infection $(90 \% O$. circumcincta) showed marked pathophysiological disturbances, and particularly a doubling of plasma pepsinogen levels, albumin catabolism and losses of plasma proteins into the gastrointestinal tract and that, if larval challenge was continued, these effects could persist for several months (Stevenson, 1989).

These studies indicated that, whilst elevated plasma pepsinogen concentrations are normally associated with the emergence of mature larvae from gastric glands (Holmes \& Maclean, 1971), they may also be associated with increased mucosal permeability, possibly as a result of an immune hypersensitivity reaction induced by ingested larvae (Anderson, 1973; Armour et al. 1979).

The possible impact of this reaction on the reproductive performance of immune ewes under larval challenge with $O$. circumcincta was recently examined by Jeffcoate et al. (1988). It was found that ovulation rates were depressed in challenged ewes relative to unchallenged controls, but not to a significant level, and there was no effect on lambing rate or lamb birth weight. However, when ewes were challenged at the time of parturition they became susceptible to infection, and a periparturient rise in numbers of parasite eggs in the faeces occurred. The reasons for this loss of immunity at parturition and the possible impact of larval challenge on the digestive efficiency of immune animals, however, remain largely unknown.

\section{CONCLUSIONS}

Despite numerous studies over the past decade much remains unknown about the processes which affect the nutritional consequences of gastrointestinal infections of ruminants. 
Results of field production studies are frequently difficult to interpret because of contributing factors which cannot be controlled. Most recent advances in the understanding of parasitic infections have been undertaken under more controlled situations in the laboratory where future work needs to identify further the specific mechanisms causing protein and energy metabolic derangements in parasitized ruminants. For example, considerations of the effects of gastrointestinal parasites on digestive function of the ruminant have generally ignored the rumen and concentrated on changes at, and distal to, the site(s) of infection. However, there have been indications of important changes occurring in the rumen (e.g. Steel, 1972; Rowe et al. 1988), and infection with $H$. contortus has shown an increase in methane production (Stevenson, 1989).

Increased use of calorimetry and carcass whole-body composition methods would further an understanding of the partitioning of dietary energy and protein accretion in a number of different important gastrointestinal parasite infections. These studies should ideally examine the effects over a range of dietary energy and protein intakes.

It is appreciated that the cost of such studies would be considerable, particularly so where bovine diseases are studied. Nevertheless, the nutritional and production consequences of anthelmintic therapy programmes constantly being evolved, using new drugs and delivery systems or timed treatments, are critically important.

The disturbances of feed intake, protein and energy metabolism and fluid balance reflect systemic responses to infection. Systemically activated mediators may well play a role in the net results of metabolic and physiological disturbances caused by gastrointestinal nematode infections of ruminants. Hormonal changes must underly many alterations to host function which future work still has to identify.

Clearly, a continued multi-disciplinary approach is essential in view of the amassed evidence of pathophysiological and nutritional consequences of a range of gastrointestinal parasite infections.

\section{REFERENCES}

Abbott, E. M. (1982). Dietary influences on the pathophysiology of ovine haemonchosis. PhD Thesis, University of Glasgow.

Abbott, E. M., Parkins, J. J. \& Holmes, P. H. (1985a). Influence of dietary protein on parasite establishment and pathogenesis in Finn Dorset and Blackface lambs given a single moderate infection of Haemonchus contortus. Research in Veterinary Science 38, 6-13.

Abbott, E. M., Parkins, J. J. \& Holmes, P. H. (1985 b). Influence of dietary protein on the pathophysiology of ovine haemonchosis in Finn Dorset and Scottish Blackface lambs given a single moderate infection. Research in Veterinary Science 38, 54-60.

Abbott, E. M., Parkins, J. J. \& Holmes, P. H. (1986). The effect of dietary protein on the pathogenesis of acute ovine haemonchosis. Veterinary Parasitology 20, $291-306$.

Albers, G. A. A. (1981). Genetic resistance to experimental Cooperia oncophora infections in calves. PhD Thesis, University of Wageningen, The Netherlands.

Alexander, H. D. \& Kiesel, G. K. (1965). The effect of blood loss on weight gain, haemoglobin and haematocrit in lambs fed different levels of protein. Auburn Veterinarian 12, 114-129.

Anderson, N. (1973). Trichostrongylid infections of sheep in a winter rainfall region. II. Epizootiological studies in the western district of Victoria, 1967-68. Australian Journal of Agricultural Research 24, 599-611.

Armour, J., Bairden, K., Duncan, J. L., Jennings, F. W. \& Parkins, J. J. (1979). Observations on ostertagiasis in young cattle over two grazing seasons with specific reference to plasma pepsinogen levels. Veterinary Record 105, 500-503.

Armour, J., Bairden, K., Duncan, J. L., Jones, R. M. \& Bliss, D. H. (1981). Studies on the control of bovine ostertagiasis using a morantel sustained release bolus. Veterinary Record 108, 532-535.

Armour, J., Bairden, K., Holmes, P. H., Parkins, J. J., Ploeger, H., Salmail, S. K. \& McWilliam, P. N. (1987). Pathophysiological and parasitological studies on Cooperia oncophora infections in calves. Research in Veterinary Science 42, 373-381.

Armour, J., Jarrett, W. F. H. \& Jennings, F. W. (1966). Experimental Ostertagia circumcincta infections in sheep: development and pathogenesis of a single infection. American Journal of Veterinary Research 27, 1267-1278.

Armour, J., Jennings, F. W., Murray, M. \& Selman, I. (1973). Bovine ostertagiasis. In Helminth Diseases of Cattle, Sheep und Horses in Europe. [G. M. Urquhart and J. Armour, editors]. Glasgow: Robert Maclehose \& Co. 
Armour. J. \& Ogbourne, C. P. (1982). Bovine ostertagiasis: A Review and Annotated Bibliography; Commonwealth Institute of Parasitology Miscellaneous Publication no. 7. Farnham Royal: Commonwealth Agricultural Bureaux.

Arundel, J. H. (1985). In Resistance in Nematodes to Anthelmintic Drugs, vol. 4, pp. 45-55 [N. Anderson and P. J. Waller, editors]. Parkeville, Victoria: CSIRO Division of Animal Health, and Australian Wool Corporation.

Baker, N. F. (1979). Economic impact and control of parasitism in dairy cattle. Bovine Practitioner 14, 42-49.

Barger, I. A. \& Southcott, W. H. (1975). Trichostrongylosis and wool growth. The wool growth response of resistant grazing sheep to larval challenge. Australian Journal of Experimental Agriculture and Animal Husbandry 15, 167-172.

Barker. I. K. \& Titchen, D. A. (1982). Gastric dysfunction in sheep infected with Trichostrongylus colubriformis, a nematode inhabiting the small intestine. International Journal for Parasitology 12, 345-356.

Behm. C. A. \& Bryant, C. (1985). In Resistance in Nematodes to Anthelmintic Drugs, vol. 5, pp. 57-67 [N. Anderson and P. J. Waller, editors]. Parkeville, Victoria: CSIRO Division of Animal Health, and Australian Wool Corporation.

Bell, F. R. \& Grivel, M. L. (1975). The effect of duodenal infusion on the electromyogram of gastric muscle during activation and inhibition of gastric emptying. Journal of Physiology 248, 377-391.

Berry. C. J. \& Dargic, J. D. (1976). The role of host nutrition in the pathogenesis of ovine fascioliasis. Veterinary Parasitology 2, 317-332.

Bliss, D. H., Jones, R. M. \& Conder, D. R. (1982). Epidemiology and control of gastrointestinal parasitism in lactating, grazing adult dairy cows using a morantel sustained release bolus. Veterinary Record $110,141-144$.

Bliss, D. H. \& Todd, A. C. (1973). Milk production by Wisconsin dairy cattle after deworming with Baymix. Veterinary Medicine and Small Animal Clinician 68, $1034-1038$.

Bliss, D. H. \& Todd, A. C. (1976). Milk production by Vermont dairy cattle after deworming. Veterinary Medicine and Small Animal Clinician 71, 1251-1254.

Borgsteede, F. H. M., Kloosterman, A., Oostendorp, d. \& van Tarrij, H. (1985). Effects of the use of a morantel sustained release bolus in first and second year grazing cattle. Veterinary Parasitology 18, 3949.

Bown, M. D., Poppi, D. P. \& Sykes, A. R. (1984). The effect of a mixed infection on the site of plasma protein absorption in the small intestine. Canadian Journal of Animal Science 64, (Suppl.) 197-198.

Bremner, K. C. (1969). Pathogenetic factors in experimental bovine oesophagostomosis. III. Demonstration of protein-losing enteropathy with ${ }^{51} \mathrm{Cr}$-albumin. Experimental Parasitology 24, 364-374.

Bremner, K. C. (1982). The pathophysiology of parasitic gastroenteritis of cattle. In Biology and Control of Endoparasites, Proceedings of the McMaster Animal Health Laboratory 50th Annual Symposium in Parasitology, pp. 277-289. [L. E. A. Symons, A. D. Donald and J. K. Dineen, editors]. New York: Academic Press.

Bueno, L., Dakkak, A. \& Fioramonti, J. (1982). Gastro-duodenal motor and transit disturbances associated with Haemonchus contortus infection in sheep. Parasitology 84, 367-374.

Coop, R. L. (1982). The impact of subclinical parasitism in ruminants. In Parasites - Their World and Ours, pp. 439-450. [D. F. Mettrick and S. S. Desser, editors]. Amsterdam: Elsevier Biomedical Press.

Coop, R. L. \& Angus, K. W. (1975). The effect of continuous doses of Trichostrongylus colubriformis larvae on the intestinal mucosa of sheep and on liver vitamin A concentration. Parasitology $70,1-9$.

Coop. R. L. \& Field, A. C. (1983). Effect of phosphorus intake on growth rate, food intake and quality of the skeleton of growing lambs infected with the intestinal nematode Trichostrongylus vitrinus. Research in Veterinary Science 35, 175-181.

Coop, R. L., Field, A. C., Graham, R. B., Angus, K. W. \& Jackson, F. (1986). Effect of concurrent infection with Osterlagia circumcincta and Trichostrongylus vitrinus on the performance of lambs. Research in Veterinary Science 41, 241-245.

Coop, R. L., Jackson, F., Graham, R. B. \& Angus, K. W. (1988). Influence of two levels of concurrent infection with Ostertagia circumcincta and Trichostrongylus vitrinus on the growth performance of lambs. Research in Veterinary Science 45, 275-280.

Coop. R. L., Sykes, A. R. \& Angus, K. W. (1982). The effects of three levels of intake of Ostertagia circumcincta larvae on growth rate, food intake and body composition of growing lambs. Journal of Agricultural Science 98 , 247-255.

Dargie, J. D. (1975). Applications of radioisotope techniques to the study of red cell and plasma metabolism in helminth diseases of sheep. In Pathogenic Processes in Parasitic Infections, pp. 1-26 [A. E. R. Taylor and R. Muller, editors]. Oxford: Blackwell Scientific Publications.

Dargie, J. D. (1980). The pathophysiological effects of gastroutestinal and liver parasites in sheep. In Digestive Physiology and Metabolism in Ruminants, pp. 349-371 [Y. Ruckebusch and P. Thivend, editors]. Lancaster: MTP Press.

Donald, A. D. (1979). Effects of parasites and disease on wool growth. In Physiological and Environmental Limitations to Wool Growth, pp. 99-114 [J. L. Black and P. J. Reis, editors]. Armidale, NSW: The University of New England Publishing Unit.

Downey, N. E., O'Shea, J. \& Spillane, T. A. (1974). Preliminary observations on the use of low-level medication in calves' drinking water as a means of endoparasite control. Irish Veterinary Journal 28, 221-222. 
Egerton, J. R., Suhayda, D. \& Eary, C. H. (1986). Prophylaxis of nematode infections in cattle with an indwelling rumino-reticular ivermectin sustained release bolus. Veterinary Parasitology 22, 67-75.

Entrocasso, C. M. (1984). Production and metabolism studies of bovine trichostrongylosis. PhD Thesis, University of Glasgow.

Entrocasso, C., Parkins, J. J., Armour, J., Bairden, K. \& McWilliam, P. N. (1986a). Metabolism and growth studies in housed calves given a morantel sustained release bolus and exposed to natural trichostrongyle infection. Research in Veterinary Science 40, 65-75.

Entrocasso, C., Parkins, J. J., Armour, J., Bairden, K. \& McWilliam, P. N. (1986b). Production, parasitological and carcase evaluation studies in steers exposed to trichostrongyle infection and treated with a morantel bolus or fenbendazole in two consecutive grazing seasons. Research in Veterinary Science 40, 76-85.

Fellenius, E., Berglindh, T., Sachs, G., Olbe, L., Elander, B., Sjöstrand, S. \& Wallmark, B. (1981). Substituted benzimidazoles inhibit gastric acid secretion by blocking $\left(\mathrm{H}^{+}+\mathrm{K}^{+}\right)$ATPase. Nature 290, 159-161.

Fox, M. T., Gerrelli, D., Pitt, S. R., Jacobs, D. E., Gill, E. M. \& Gale, D. L. (1989a). Pathophysiology of Ostertagia ostertagi infection in the calf: effects of a trickle challenge on appetite, digestibility, rate of passage of digesta and liveweight gain. Research in Veterinary Science.

Fox, M. T., Gerrelli, D., Pitt, S. R., Jacobs, D. E., Hart, I. C. \& Simmonds, A. D. (1987). Endocrine effects of a single infection of Ostertagia ostertagi in the calf. International Journal for Parasitology 17, 1181-1185.

Fox, M. T., Gerrelli, D., Schivalkar, P. \& Jacobs, D. E. (1989 b). Effect of omeprazole treatment on feed intake and blood gastrin and pepsinogen levels in the calf. Research in Veterinary Science 46, 280-282.

Garriz, C. A., Gallinger, M. M., Touraille, C., Steffan, P. E., Fiel, C. A., Ambrustola, R. R., Biondani, C. A., Zamorano, M. \& Bulman, G. M. (1987). Gastrointestinal parasitism: its effects on muscle, fat and bone composition of the carcase and organoleptic characteristics of meat. In The Economic Impact of Parasitism in Cattle. Proceedings XXIII World Veterinary Congress MSD AGVET Symposium, [M. D. Leaning, J. Gueuero and R. C. Hipple, editors].

Gregory, P. C. (1985). Parasitic infection and stomach motility: relation to intestinal motility and food intake. In The Ruminant Stomach, Veterinary Research Communications, vol. 1. [L. A. A. Ooms, A. D. Degryse and R. Marsboom, editors]. Marlow, Bucks: Janssen Research Foundation.

Gregory, P. C., Wenham, G., Poppi, D., Coop, R. L., Macrae, J. C. \& Miller, S. J. (1985). The influence of a chronic subclinical infection of Trichostrongylus colubriformis on gastrointestinal motility and digesta flow in sheep. Parasitology 91, 381-396.

Grovum, W. L. (1979). Factors affecting the voluntary intake of food by sheep. 2. The role of distension and tactile input from compartments of the stomach. British Journal of Nutrition $42,425-436$.

Grovum, W. L. (1981). Factors affecting the voluntary intake of food by sheep. 3. The effect of intravenous infusions of gastrin, cholecystokinin and secretin on motility of the reticulo-rumen and intake. British Journal of Nutrition 45, 183-201.

Grovum, W. L. \& Phillips, G. D. (1978). Factors affecting the voluntary intake of food by sheep. 1. The role of distension, flow-rate of digesta and propulsive motility in the intestines. British Journal of Nutrition 40, 323-336.

Hodgson, J. C. \& Jessop, N. S. (1987). Effect of mode of anthelmintic treatment on rumen short-chain fatty acid concentrations in sheep. Veterinary Record 120, 553-554.

Holmes, P. H. (1985). Pathogenesis of trichostrongylosis. Veterinary Parasitology 18, 89-101.

Holmes, P. H. (1986). Pathophysiology of nematode infections. In Proceedings of The Sixth International Congress of Parasitology, [M. J. Howell, editor]. Canberra: Australian Academy of Science.

Holmes, P. H., Abbott, E. M. \& Parkins, J. J. (1986). Use of nuclear techniques to investigate the influence of host nutrition on the pathogenesis of ovine haemonchosis. In Nuclear Techniques Aimed at Improving Meat, Milk and Wool Production from Ruminant Animals, Vienna: International Atomic Energy Agency.

Holmes, P. H. \& Bremner, K. C. (1971). The pathophysiology of ovine ostertagiasis. Water balance and turnover studies. Research in Velerinary Science 12, 381-383.

Holmes, P. H., Dargie, J. D., Maclean, J. M. \& Mulligan, W. (1968). The anaemia in fascioliasis: experiments with ${ }^{51} \mathrm{Cr}$-labelled red cells. Journal of Comparative Pathology 78, 415-420.

Holmes, P. H. \& Maclean, J. M. (1971). The pathophysiology of ovine ostertagiasis: A study of the changes in plasma protein metabolism following single infections. Research in Veterinary Science 12, 265-271.

Jacobs, D. E., Pilkington, J. G., Foster, J., Fox, M. T. \& Oakley, G. A. (1987). 'Front loaded' oxfenbendazole pulse release bolus for the suppression of parasitism in grazing calves: a field study. Veterinary Record 121 , 403-404.

Jara, W., Sumano, H. \& Ocampo, L. (1984). Effects of three benzimidazole anthelmintics on the ruminal fermentation ability of sheep. Veterinary Record 115, 565-566.

Jeffcoate, I. A., Holmes, P. H., Fishwick, G., Boyd, J., Bairden, K. \& Armour, J. (1988). Effects of trichostrongyle larval challenge on the reproductive performance of immune ewes. Research in Veterinary Science 45, $234-239$.

Jones, R. M. (1981). A new method of control of gastrointestinal parasites in grazing calves. In Epidemiology and Control of Nematodiasis in Cattle, pp. 349-363 [P. Nansen, R. J. Jørgensen and E. J. L. Soulsby, editors]. The Hague, Netherlands: Martinus Nijhoff.

Jones, R. M., Pott, J. N. \& Cornwell, R. L. (1978). Low level feed administration of morantel tartrate in the prophylaxis of experimental nematode infections in lambs and calves. British Veterinary Journal 134, 166-170. 
Jones, W. O. \& Symons, L. E. A. (1982). Protein synthesis in the whole body, liver, skeletal muscle and kidney cortex of lambs infected by the nematode Trichostrongylus colubriformis. International Journal for Parasitology 12, 295-301.

Jordan, H. E., Cole, N. A., McCroskey, J. E. \& Ewing, S. A. (1977). Influence of Ostertagia ostertagi and Cooperia infections on the energetic efficiency of steers fed a concentrate ration. American Journal of Veterinary. Research 38, 1157-1160.

Kimambo, A. E., MacRae, J. C., Walker, A., Watt, C. F. \& Coop, R. L. (1988). Effect of prolonged subclinical infection with Trichostrongylus colubriformis on the performance and nitrogen metabolism of growing lambs. Veterinary Parasitology 28, 191-203.

Kloosterman, A. (1971). Observation of the epidemiology of trichostrongylosis of calves. PhD Thesis. Agricultural University, Wageningen. The Netherlands.

Kloosterman, A. \& Henken, A. M. (1987). Effect of gastrointestinal nematodes on metabolism in calves. In Energy Metabolism in Farm Animals, pp. 352-371 [M. W. A. Verstegen and A. M. Henken, editors]. Dordrecht, The Netherlands: Martinus Nijhoff Publishers.

Kruse, G. O. W. (1986). Aspekte in der Anwendung des Paratect Bolus bei Rindern zur Verhinderung der parasitaren Gastroenteritis. (Aspects of the application of Paratect bolus for the prevention of parasitic gastroenteritis in cattle.) Praktische Tierarzt 67, 228-252.

Leng, R. A. (1981). Nutrition and metabolism of parasitized and non-parasitized ruminants: some approaches for studying the mode of action of parasites. In Isotopes and Radiation in Parasitology IV, 191-206. Vicnna: International Atomic Energy Agency.

Leyva, V., Henderson, A. E. \& Sykes, A. R. (1982). Effect of daily infection with Osterlagia circumcincta larvae on food intake, milk production and wool growth. Journal of Agricultural Science 99, 249-259.

McBeath, D. G., Dean, S. P. \& Preston, N. K. (1979). The effect of a preparturient fenbendazole treatment on lactation yield in dairy cows. Veterinary Record 105, 507-509.

MacDonald, T. T. \& Ferguson, A. (1978). Small intestinal epithelial cell kinetics and protozoal infection in mice. Gastroenterology 74, 496-500.

McKellar, Q., Duncan, J. L., Armour, J. \& McWilliam, P. N. (1986). Response to transplanted adult Ostertagia ostertagi in calves. Research in Veterinary Science 40, 367-371.

MacRae, J. C., Smith, J. S., Sharman, G. A. M., Corrigall, W. \& Coop, R. L. (1982). Energy metabolism of lambs infected with Trichosirongylus colubriformis. In Energy Metabolism of Farm Animals, European Association of Animal Production Publication no. 29, pp. 112-115 [A. Ekern and F. Sundstøl, editors]. Aas. Norway: The Agricultural University of Norway.

Marriner, S. (1986). Anthelmintic drugs. Veterinary Record 118, 181-184.

Michel, J. F., Richards, N., Altman, J. F. B., Mulholland, J. R., Gould, C. M. \& Armour, J. (1982). Effect of anthelmintic treatment on the milk yield of dairy cows in England, Scotland and Wales. Veterinary Record 111 , 546-550.

Mitchell, G. B. B. (1987). Assessment of an oxfenbendazole pulsed release bolus for control of parasitic gastroenteritis in calves in a rotational grazing system. Veterinary Record 121, 377-378.

Morgan, D. W. T. \& Rowlands, D. (1986). Proceedings of the XIVth World Congress on Diseases of Cattle, Dublin, p. 136.

Parkins, J. J., Bairden, K. \& Armour, J. (1982a). Ostertagia ostertagi in calves: a growth, nitrogen balance and digestibility study conducted during winter feeding following thiabendazole anthelmintic therapy. Journal of Comparative Pathology 92, 219-227.

Parkins, J. J., Bairden, K. \& Armour, J. (1982 b). Ostertagia ostertagi in calves: growth, nitrogen balance and digestibility studies conducted during winter feeding following different fenbendazole therapy programmes. Research in Veterinary Science 321, 74-78.

Parkins, J. J., Holmes, P. H. \& Bremner, K. (1973). The pathophysiology of ovine ostertagiasis: some nitrogen balance and digestibility studies. Research in Veterinary Science 14, 21-28.

Parkins, J. J., Taylor, L. M., Holmes, P. H., Armour, J., Bairden, K. \& Salman, S. (1990). Pathophysiological and parasitological studies on a concurrent infection of Ostertagia ostertagi and Cooperia oncophora in calves. Research in Veterinary Science (In the Press.)

Parkins, J. J., Taylor, L. M., Reid, J., Bairden, K., Aitchison, T. C. \& McWilliam, P. N. (1988). Activity of intraruminally administered levamisole against Ostertagia circumcincta in lambs. Veterinary Record 122, $513-514$.

Pope, D. G., Wilkinson, P. K., Egerton, J. R. \& Conroy, J. (1985). Oral controlled-release delivery of ivermectin in cattle via an osmotic pump. Journal of Pharmaceutical Sciences 74, 1108-1110.

Poppi, D. P., Macrae, J. C., Brewer, A. \& Coop, R. L. (1986). Nitrogen transactions in the digestive tract of lambs exposed to the intestinal parasite Trichostrongylus colubriformis. British Journal of Nutrition 55, 593-602.

Poppi, D. P., Macrae, J. C., Brewer, A. C., Dewey, P. J. S. \& Walker, A. (1985). Calcium and phosphorus absorption in lambs exposed to Trichostrongylus colubriformis. Journal of Comparative Pathology 95, 453-464.

Poppi, D. P., MacRae, J. C. \& Corrigall, W. (1981). Nitrogen digestion in sheep infected with intestinal parasites. Proceedings of the Nutrition Society 40, 1164.

Randall, R.W. \& Gibbs, H. C. (1981). Effect of clinical and sub-clinical gastrointestinal helminthiasis on digestion and energy metabolism in calves. American Journal of Veterinary Research 42, $1730-1734$. 
Reveron, A. E., Topps, J. H. \& Selman, A. L. (1974). Mineral metabolism and skeletal development of lambs affected by Trichostrongylus colubriformis. Research in Veterinary Science 16, 310-319.

Ritchie, J. D. S., Anderson, N., Armour, J., Jarrett, W. F. H., Jennings, F. W. \& Urquhart, G. M. (1966). Experimental Ostertagia ostertagi infections in calves: parasitology and pathogenesis of a single infection. American Journal of Veterinary Research 27, 659-667.

Roseby, F. B. (1977). Effects of Trichostrongy/us colubriformis (Nematoda) on the nutrition and metabolism of sheep. III. Digesta flow and fermentation. Australian Journal of Agricultural Research 28, 155-164.

Roseby, F. B. \& Leng, R. A. (1974). Effects of Trichostrongylus colubriformis (Nematoda) on the nutrition and metabolism of sheep. II. Metabolism of urea. Australian Journal of Agricultural Research 25, 363-367.

Rowe, J. B., Abbott, E. M., Dargie, J. D. \& Holmes, P. H. (1982). The effect of haemonchosis and blood loss into the abomasum on nitrogen digestion in sheep. Proceedings of the Nutrition Society 41, 74A.

Rowe, J. B., Nolan, J. V., de Chaneet, G., Teleni, E. \& Holmes, P. H. (1988). The effect of haemonchosis and blood loss into the abomasum on digestion in sheep. British Journal of Nutrition 59. 125-139.

Ruckebusch, Y. (197I). The effects of pentagastrin on the motility of the ruminant stomach. Experientia 27, 1185-1186.

Soll, M. D., Carmichael, I. H. \& Harvey, R. G. (1988). Prophylactic efficacy of sustained-release ivermectin against induced nematode infestations in cattle. Journal of South African Veterinary Association 59, 9-11.

Steel, J. W. (1972). Effects of the intestinal nematode Trichostrongylus colubriformis on ruminal acetate metabolism in young sheep. Proceedings of the Australian Society of Animal Production 9, 402-407.

Steel, J. W. (1974). Pathophysiology of gastrointestinal nematode infections in the ruminant. Proceedings of the Australian Sociely of Animal Production 10, 139-147.

Steel, J. W. (1978). Inter-relationships between gastrointestinal helminth infection, nutrition and impaired productivity in the ruminant. In Recent Advances in Animal Nutrition, pp. 98-109. [D. J. Farrell, editor]. Armidale, NSW: University of New England Printing Unit.

Steel, J. W., Jones, W. O. \& Symons, L. E. A. (1982). Effects of a concurrent infection of Trichostrongylus colubriformis on the productivity and physiology and metabolic responses of lambs infected with Ostertagia circumcincta. Australian Journal of Agricultural Research 33, 131-140.

Steel, J. W. \& Symons, L. E. A. (1982). Nitrogen metabolism in nematodiasis of sheep in relation to productivity. In Biology and Control of Endoparasites, Proceedings of the McMaster Animal Health Laboratory S0ih Annual Symposium in Parasitology, pp. $235 \cdots 256$ [L. E. A. Symons, A. D. Donald and J. K. Dineen, editors]. New York: Academic Press.

Steel, J. W.. Symons, L. E. A. \& Jones, W. O. (1980). Effects of level of larval intake on the productivity and physiology and metabolic responses of lambs infected with Trichostrongylus colubriformis. Australian Journal of Agricultural Research 31, 821-828.

Stevenson, A. G. (1989). Some effects of trichostrongylidosis on metabolism and production of sheep. PhD Thesis, University of Glasgow.

Sykes, A. R. (1982). Nutritional and physiological aspects of helminthiasis in sheep. In Biology and Control of Endoparasites, Proceedings of the McMaster Animal Health Laboratory 50th Anniversary Symposium in Parasilology pp. 217-230 [L. E. A. Symons, A. D. Donald and J. K. Dineen, editors]. New York: Academic Press.

Sykes, A. R. (1983). Effects of parasitism on metabolism in the sheep. In Sheep Production (Nottingham Easter School in Agricultural Science no. 35), pp. 317-334 [W. Haresign, editor]. London: Butterworths.

Sykes, A. R. \& Coop, R. L. (1976). Intake and utilisation of food by growing lambs with parasite damage in the small intestine caused by daily dosing with Trichostrongylus colubriformis larvae. Journal of Agriculiural Science 86, 507-515.

Sykes, A. R. \& Coop, R. L. (1977). Intake and utilisation of food by growing sheep with abomasal damage caused by daily dosing with Ostertagia circumcincta larvae. Journal of Agricultural Science 88, 671-677.

Sykes, A. R., Coop, R. L. \& Angus, K. W. (1977). The influence of chronic Ostertagia circumcincta infection on the skeleton of growing sheep. Journal of Comparative Pathology 87, 521-529.

Sykes, A. R., Coop. R. L. \& Angus, K. W. (1979). Chronic infection with Trichostrongylus vitrinus in sheep: some effects on food utilisation, skeletal growth and certain serum constituents. Research in Velerinary Science 26, $372-377$.

Symons, L. E. A. (1985). Anorexia: occurrence, pathophysiology and possible causes in parasitic infections. Advances in Parasitology 24, 103-133.

Symons, L. E. A. \& Jones, W. O. (1970). Nematospiroides dubius, Nippostrongylus brasiliensis and Trichostrongylus colubriformis: Protein digestion in infected animals. Experimental Parasitology 27, 496-506.

Symons, L. E. A. \& Jones, W. O. (1975). Skeletal muscle, liver and wool protein synthesis by sheep infected by the nematode Trichostrongylus colubriformis. Australian Journal of Agricultural Research 26. 1063-1072.

Symons, L. E. A. \& Jones, W. O. (1983). Intestinal protein synthesis in guinea pigs infected with Trichostrongylus colubriformis: protein digestion in infected animals. Experimental Parasitology 27, 496-506.

Symons, L. E. A., Stee], J. W. \& Jones, W. O. (1981 $a$ ). Effects of level of larval intake on the productivity and physiology and metabolic responses of lambs infected with Ostertagia circumcincta. Australian Journal of Agricultural Research 32, 139-148.

Symons, L. E. A., Steel, J. W. \& Jones, W. O. (1981 b). Tissue protein metabolism in parasitised animals. In Isotopes and Radiation in Parasitology 4, 171-178. Vienna: International Atomic Energy Agency. 
Taylor, L. M. (1988). Aspects of nitrogen metabolism in ruminants in health and disease. PhD. Thesis, University of Glasgow.

Taylor, L. M., Parkins, J. J., Armour, J., Bairden, K., Holmes, P. H. \& McWilliam, P. N. (1989). Pathophysiological and parasitological studies on Ostertagia ostertagi infections in calves. Research in Veterinary Science 46, 218-225.

Taylor. S., Mallon, T. R. \& Kenny, J. (1985). Comparison of early season suppressive anthelmintic prophylactic methods for parasitic gastroenteritis and bronchitis in calves. Veterinary Record 117, 521-524.

Thomas, R. J. \& Ali, D. A. (1983). The effect of Haemonchus contortus infection on the pregnant and lactating ewe. International Journal for Parasitology 13, 393-398.

Titchen, D. A. (1982). The role of hormones in the reactions of the host to enteric parasites. In Parasites - Their World and Ours, pp. 245-247 [D. F. Mettrick and S. S. Desser, editors]. Amsterdam: Elsevier Biomedica! Press.

Van Adrichem, P. W. M., Los, M. J. N., Vogt, J. E. \& Wetzlar, Y. (1987). The effect of a subclinical haemonchus infection on the metabolism of sheep. In Energy Metabolism of Farm Animals, [M. W. A. Verstegen and A. M. Henken, editors]. Dordrecht, The Netherlands: Martinus Nijhoff Publishers.

Verstegen, M. W. A., van der Hel, W., Albers, G. A. A. \& Kloosterman, A. (1989). Effect of trichostrongylid infection on feed intake, metabolic rate and protein gain of calves. Journal of Physiology and Animal Nutrition (In press).

Wilson, W. D. \& Field, A. C. (1983). Absorption and secretion of calcium and phosphorus in the alimentary tract of lambs infected with daily doses of Trichostrongylus colubriformis and Ostertagia circumcincta larvae. Journal of Comparative Pathology 93, 61-71.

Yakoob, A. Y.. Holmes, P. H., Parkins, J. J. \& Armour, J. (1983). Plasma protein loss associated with gastrointestinal parasitism in grazing sheep. Research in Veterinary Science 34, 58-63.

Zemmelink, G. (1980). Effect of selective consumption on voluntary intake and digestibility of tropical forages. Agricultural Research Reports no. 896. Wageningen: PUDOC. 